\title{
ASPECTS OF MENTAL HEALTH PROTECTION IN MILITARY SERVICE IN THE CONDITIONS OF MILITARY ACTION AND IN THE ADAPTIVE PERIOD
}

\author{
Iryna Guzenko
}

National Academy of ground Forces named after hetman Petro Sagaidachniy, Lviv, Ukraine

\begin{abstract}
For the last five years, a topical issue for sociologists, psychologists, and medics has been the study, diagnosis, and use of methods of treating traumatic and post-traumatic stress disorders in servicemen who have returned from combat. Mental health care in warfare is the skilled care of soldiers in combat, as well as in the transition from military service to civilian life based on training and rehabilitation, and complete recovery from post-traumatic stress disorder (PTSD).
\end{abstract}

Keywords. Stress, psycho-traumatic factors, post-traumatic stress disorder, flushes, intrusions Стрес, психотравмуючі чинники, посттравматичний стресовий розлад, флеш беки, інтрузії.

\section{АСПЕКТИ ОХОРОНИ ПСИХІЧНОГО ЗДОРОВ'Я ВІЙСБКОВОСЛУЖБОВЦІВ В УМОВАХ БОЙОВИХ ДІЙ І В ПОСТБОЙОВИЙ АДАПТИВНИЙ ПЕРІОД}

Бойові дії на Сході України, що на сьогоднішній день $є$ справжньою війною, спровокували хвилю проблем психосоціальної адаптації, в якій посттравматичний стресовий розлад набув нових якісних i кількісних характеристик. Актуальним питанням сьогодення $\epsilon$ вивчення проблем збереження психічного здоров'я військовослужбовців в бойових умовах та в період адаптації до умов мирного життя.

Війна приносить не тільки фізичні, а й душевні травми. Учасники бойових дій, часто навіть не усвідомлюючи цього, несуть в собі вантаж болю довгі роки. Одні можуть подолати ці проблеми самостійно. Іншим необхідна психологічна допомога і підтримка протягом усього життя.

Військовослужбовці, виконуючи особливі функції, виявляються найбільш уразливими у фізичному й моральному аспектах і несуть основний тиск всіх наслідків збройних конфліктів. Тому, з очевидністю, випливає багатозначність психологічних перевантажень, емоційно-стресової напруженості військовослужбовців, котрі беруть участь у збройних конфліктах. Екстремальність умов бойових дій виражається в інтенсивності стрес-фактора, раптовості, небезпеці, тотальному впливі на великі групи людей, а також тривалим i важким плином постекстремальних психічних розладів. Екстремальні умови діяльності з психологічної точки зору характеризуються наявністю сильного психотравмуючого впливу подій і обставин на психіку військовослужбовця. Унаслідок багаторазово раптово діючих психотравмуючих чинників в екстремальних умовах життя, виникають групові психогенні розлади, інакше кажучи, групові психози. Страх, безвихідь, пригніченість та інші емоційні стани при продовженні дії психотравмуючих факторів 
призводять до виникнення психологічного стресу. Разом із бойовим досвідом військовослужбовці отримують фізичні й психологічні травми, а їхня психіка зазнає значних змін. Досвід ООС (АТО) засвідчує, що основною реакцією військовослужбовців на бойові події $є$ бойовий стрес, спричинений стресфакторами бойової обстановки. 3 часом у військовослужбовця з'являються симптоми психічних розладів, викликаних високою нервово-психічною напругою безпосередньо в ході виконання службово-бойових завдань. Вони поділяються на поведінкові реакції (сильне тремтіння, апатія, загальмованість рухів, слізливість, дратівливість і злість, буйство), психічні реакції (нездатність концентрувати увагу, часткова або повна втрата пам'яті, швидкості мислення й ослаблення волі, чутливість до шуму), соматичні реакції (ослаблення зору й слуху, часте сечовипускання, розлади шлунку, утруднене дихання, сильна напруга м'язів, прискорене серцебиття, болі в попереку).

Очевидно, що чим більш інтенсивний бойовий стрес пережив військовослужбовець у бойовій обстановці, тим більше ймовірність виникнення в нього негативних психологічних наслідків після припинення впливу бойових стресорів. Наявність у житті події, що виходить за рамки звичайного людського досвіду, є фактором, що травмує і дозволяє включити людину до групи ризику щодо виникнення ПТСР.

Посттравматичний стресовий розлад (ПТСР) - це важкий психічний стан. Якщо рани можуть зажити, а шрами, зрештою, стягнуть шкіру, - то психічний розлад може дати про себе знати і через роки після травми.

Симптомами посттравматичного стресового розладу є інтрузії (повторювані нав'язливі спогади, які виникають спонтанно, але при цьому людина перебуває в моменті "тут і зараз", та флешбеки (мимовільне і непередбачуване пожвавлення травматичного досвіду через надзвичайно яскраві спогади, що тривають від кількох секунд до кількох годин, під час яких ветеранам здається, що страшна реальність 3 минулого вторгається в їх справжнє життя.).

Потрібно говорити про потужні стресогенні фактори. А у бійця це в сто разів більше, в сто разів більш посилені спогади, які не дають йому спокою, виникають спонтанно і некеровані ним. У таких бійців відбулися збої в адаптаційному механізмі.

Згодом учасники таких екстремальних подій починають страждати на психічні розлади та відчувати труднощі у процесі адаптації до мирного життя. Участь у бойових діях впливає на свідомість людини, піддаючи іiі серйозним якісним змінам. Посттравматичні стресові порушення сприяють формуванню специфічних сімейних відносин, особливих життєвих сценаріїв і можуть впливати на все подальше життя людини.

Таким чином, ефективна охорона психічного здоров'я передбачає безперервний моніторинг чинників стресу та наслідків стресу. Навіть найкращі заходи 3 охорони психічного здоров'я не можуть усунути всіх проблем, пов'язаних зі стресом, які здатні впливати на професійне функціонування чи стан здоров'я. Важливість кваліфікованого піклування про солдатів в зоні бойових дій, а також під час переходу від військової служби до цивільного життя засноване на навчанні та реабілітації, а також повному відновленні після посттравматичних стресових розладів (ПТСР). Процес одужання після фізичних та емоційних травм, отриманих під час збройних конфліктів, возз'єднання із сім'єю та реінтеграція, оперативна психіатрія, методи запобігання самогубствам $\epsilon$ 
першочерговим завданням у суспільстві 3 метою збереження психічного та фізичного здоров'я військовослужбовців.

\section{СПИСОК ВИКОРИСТАНИХ ДЖЕРЕЛ}

1. Алещенко В.І. Психологічна реабілітація військовослужбовців 3 постстресовими психічними розладами: Навчальний посібник / В.І. Алещенко, О.Ф. Хміляр. - Харків, ХУПС. - 2005. - 84 с.

2. Ломакін Г.І. Прояви порушень реадаптації учасників бойових дій у системі суспільних відносин / Геннадій Іванович Ломакін - Проблеми емпіричних досліджень у психології, 6-7 грудня 2012p., Київ: Матеріали VI Міжнародної науково-практичної конференції / За ред. І.В. Данилюка, І.В. Ващенко. - К.; OBC, 2012. - c. 94-100.

3. Охорона психічного здоров'я в умовах війни [Текст] : [пер. $з$ англ.] : у 2 т. / [Айлін Кім, Алан Л. Петерсон, Альберт Ю. Сайто та ін.] ; Америк.-укр. мед. фундація. - Київ : Наш формат, 2017. - ISBN 978-966-2502-13-8.

4. Психологія бою: Посібник/Грицевич Т.Л., Гузенко I.М., Капінус О.С., Мацевко Т.М., Романишин А.М.; за ред.А.М. Романишина. - 352 с. 